\title{
Valerie Møller: A Pioneer in South African Quality of Life Research
}

\author{
Valerie Møller
}

Received: 28 February 2013 / Accepted: 15 April 2013 /

Published online: 16 June 2013

(C) Springer Science+Business Media Dordrecht and The International Society for Quality-of-Life Studies (ISQOLS) 2013

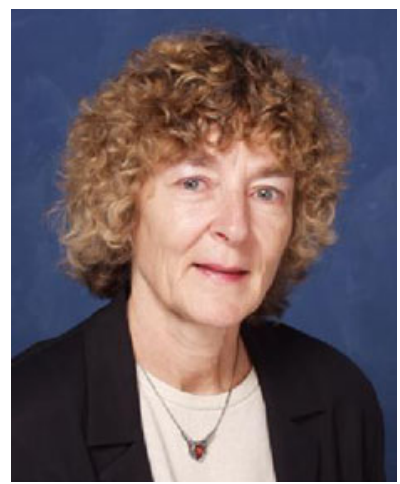

Professor Valerie Møller is Professor Emeritus of Quality of Life Studies at Rhodes University, Grahamstown, South Africa. Before that she was director of the Institute of Social and Economic Research at Rhodes University (1998-2006) and headed the Quality of Life Research Unit at the University of KwaZulu-Natal, Durban, South Africa, in the 1990s.

She completed her primary school education in North Carolina, USA, and her secondary and tertiary education in Zürich, Switzerland. She earned Lic. Phil and DPhil degrees from the University of Zürich, majoring in sociology. She has lived and worked in Southern Africa since 1972.

Together with the late Professor Lawrence Schlemmer she developed the first survey instruments to measure objective and subjective well-being among South Africans from all walks of life. The South African Quality of Life Trends Study has tracked happiness and life satisfaction from apartheid to the transition to democracy (1983-2012).

V. Møller $(\bowtie)$

Rhodes University, P O Box 94, Grahamstown 6140, South Africa

e-mail: v.moller@ru.ac.za 
Over the past 35 years she has studied South African quality-of-life by conventional and less conventional means: Attitude and household surveys, in-depth and focus group interviews, time-use studies, narratives, and writing competitions. She has researched a wide range of issues in relation to well-being including housing and community development, unemployment and spare time use, return migration, intergenerational relations, social assistance to alleviate poverty, food security, criminal victimisation, the spread of charismatic churches, TB and HIV-related stigma, national pride, and among the youth and the elderly.

She edited two special issues of Springer's Social Indicators Research on South African quality of life and co-edited three Springer volumes: Assessing Quality of Life and Living Conditions to Guide National Policy (with Michael R. Hagerty and Joachim Vogel), Barometers of Quality of Life Around the Globe (with Denis Huschka and Alex C. Michalos) and Quality of Life and the Millennium Challenge (with Denis Huschka). She has published over 200 research articles, book chapters, and monographs. She served as President of the International Society for Quality of Life Studies (2007-8) and hosted its 7th conference in South Africa in 2006.

\section{Selected Publications}

Møller, V. (2012). South African quality of life trends over three decades, 1980-2010. Social Indicators Research. doi:10.1007/s11205-012-0120-y.

Møller, V. (2007a). Researching quality of life in a developing country: Lessons from the South African case. In I. Gough \& J. A. McGregor (Eds.), Wellbeing in developing countries: From theory to research (pp. 242-258). Cambridge: Cambridge University Press.

Møller, V. (2007). Guest editor. Quality of life in South Africa-ten years into democracy. Social Indicators Research, 81(2).

Møller, V. (Ed.) (1997). Quality of life in South Africa. Dordrecht: Kluwer. Reprinted from Social Indicators Research, 41(1-3). 